J. Product. \& Dev., 26(4): 843-863 (2021)

\title{
IMPACT OF ROYAL JELLY, GIBBERELLIC ACID AND TESTOSTERONE TREATMENTS ON SOME PRODUCTIVE, EGG QUALITY TRAITS AND ECONOMIC EFFICIENCY IN LOCAL CHICKEN STRAIN, DURING THE SUMMER SEASON OF EGYPT.
}

\author{
A. A.Gomaa*; A. A. Rashwan*; M. I. Tawfeek*; H.M. El Kelawy* and W. \\ Ezzat** \\ 1- Animal \& Poultry Production Department, Faculty of Technology and \\ Development, Zagazig University, Zagazig, Egypt. \\ 2- Poult. Breed. Res. Dep., Anim. Prod. Res. Inst., Agric. Res. Centre, Min. of \\ Agric., Giza, Egypt. \\ E.mail: ahmedgoma413@yahoo.com,rashwanali@hotmail.com,mostawms@hotmail.com, \\ drhassan_2105@yahoo.com,dr.waheed_ezzat@yahoo.com
}

\section{ABSTRACT:}

A total number of 128 laying pullets and 16 cocks of Matrouh local strain at 140 days of age (20-24 weeks) were randomly divided into four treatment groups (32 females and 4 males / group) in completely randomized design. The injections were carried out once a week for a month (4 times injection) before sexual maturity from 20 to 24 weeks of age. The $1^{\text {st }}$ treatment group of pullets was injected with a saline solution $0.9 \%$ and was considered as a control group. The $2^{\text {nd }}$ group, was administrated into the mouth, with $0.2 \mathrm{ml}$ of distill water, which containing $200 \mu \mathrm{g}$ royal jelly $(R J) / \mathrm{kg} \mathrm{BW}$. While, the $3^{\text {rd }}$ and $4^{\text {th }}$ groups were injected subcutaneously with $0.2 \mathrm{ml}$ of saline solution $0.9 \%$, which containing 200 $\mu g / K g$ BW of each of gibberellic acid $\left(G A_{3}\right)$ or testosterone (Ts), respectively.

The obtained results revealed that the final body weight, daily feed consumption (DFC) and feed conversion ratio (FCR) of Matrouh pullets treated with $200 \mu \mathrm{g} T$, or $G A_{3}, \mathrm{~kg} \mathrm{BW}$, as well as egg production rate $(E P R)$, egg mass (EM) and egg weight (EW) were improved significantly $(P \leq 0.05)$ as compared with the control at the whole experimental period (24-48 weeks of age) compared to the control group. The lowest mortality rate (MR) 9.38 and $12.50 \%$ was significantly with $T s$ and $R J$ treated groups, respectively. While, the highest MR (\%) was 18.75 and $15.63 \%$ recorded in $\mathrm{GA}_{3}$ and control groups, respectively in laying pullets, during the total period (24-48 weeks of age). Moreover, egg shape index and egg albumin index were significantly $(P<0.05)$ increased for pullets injected 
with $200 \mu \mathrm{g} \mathrm{GA} A_{3}$ and $T s / \mathrm{kg} B W$, respectively when compared to the control group, during the period from 24-48 weeks of age. However, results obtained revealed that treated pullets with $T$ s and $R J$ increased significant $(P<0.05)$ egg albumin weight \% than the control group in the same period. The best economic efficiency and the highest net return were recorded with $\mathrm{GA}_{3}$ followed by the RJ group, while the control group recorded the lowest values during the whole experimental periods (20-48 weeks of age).

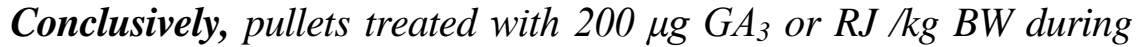
pre-sexual maturity of age (20-24 weeks) were recommended for improving most of the productive performance, as well as egg quality, highest net return and economic efficiency of Matrouh local strain during summer season in Egypt.

Keywords: Royal Jelly, Gibberellic acid, Testosterone, summer season, Productive performance, Matrouh laying pullets.

\section{INTRODUCTION}

Globally, the poultry industry is gaining significant importance among the agricultural and its allied sectors. Heat stress reduces the growth, reproductive performance, and egg production in poultry. The reduction in the productive potential of poultry that exposure to heat stresses may be attributed to the deviation of energy resources from production to adaptation pathway (Vandana et al., 2021). Also, high ambient temperatures have clear impacts on the behavior, feed and water intake, heat production, and physiological responses (body temperature, respiratory rate and heart rate) of poultry (Mutibvu et al., 2017). Generally, the types of heat stress classification of birds are as follows: acute: $27-$ $38{ }^{\circ} \mathrm{C}\left(1-24 \mathrm{~h}\right.$ ); moderate: $27-38{ }^{\circ} \mathrm{C}$ (up to 7 days); chronic or severe: $38-50{ }^{\circ} \mathrm{C}$ (7 days or more) (Guo et al., 2008). However, any deviation from these ranges, especially in the upper critical temperature instigates heat stress response on poultry birds (Pawar et al. 2016).

Royal Jelly (RJ) is an item from honey bees that is utilized to take care of in the hive just as a main nutritional source for the queen honey bee. It is partially soluble in water and has a collar around whitish to yellow, with a density (1.1 $\mathrm{g} / \mathrm{ml})$. The $\mathrm{RJ}$ is a rich source of proteins $(27 \%-41 \%)$, essential amino acids; carbohydrates (30\%); fatty acids, lipids (8\%-19\%); phytosterols, carotenes, flavonoids, vitamins and minerals that aid the bee to stay alive, as well as some other unknown active compounds (Maghsoudlou et al., 2019; Sabatini et al., 2009). It has different significant hatchlings natural exercises, including anti 
hypercholesterolaemic (Guo et al., 2007), anti-heat stress (El-Hanoun et al., 2014; Elnagar et al., 2010) and antioxidant abilities among others (Nagai et al., 2004). RJ has been reported to have steroid and testosterone hormone-type actions (Hidaka et al., 2006). Based on literatures in vivo and in vitro reports, it has been stated that RJ could inhibit lipid peroxidation (Hang et al., 2008), and also, possesses antioxidant property and may play a noteworthy role on its influences on oxidative stress ageing process in animals (Ikeda et al., 1996).

Gibberellic acid $\left(\mathrm{GA}_{3}\right)$ is a characteristic hormone found in plants and parasites and goes as a growth promoter (Silva et al., 2013). In addition, AbdelAzim (2017) announced that $\mathrm{GA}_{3}$ is one of the plant development controllers that are generally utilized in Egypt, to increase the growth of fruits and vegetables. In addition, Gawienowski and Chatterjee (1980) reported that $\mathrm{GA}_{3}$ has demonstrated in mammals a number of estrogenic hormones-like actions. Several studies showed beneficial effects of using $\mathrm{GA}_{3}$ showing androgenic and estrogenic like actions in mammals and poultry (Elkomy, 2003; El-Sebai et al., 2003; AbdelFattah et al., 2007; Elkomy et al., 2008). Abd-Elhamid et al. (1994) reported positive influences of $\mathrm{GA}_{3}$ on body weights of poultry. Askar and IsmaeIl (2012) revealed that GA3 has a positive effect on product performance and fertility of laying hens.

Testosterone (Ts) is the most well-known male hormone (Goerlich et al., 2010). The first Ts injections for stimulating ovulation were reported (Fraps, 1955). Injection of testosterone to laying hens, which have an active ovary, may stimulate ovulation, so it has been thought that the testosterone surge prior to ovulation causes LH surge, suggesting its important role in ovulation process. Furthermore, active or passive immunizations of testosterone effects lead to ovulation cease (Pehlivan et al., 2001). A preovulatory increase of testosterone causes LH surge before ovulation by influencing hypothalamic-pituitary- ovarian axis (Pehlivan et al., 2001). The mechanism of Ts was involved in ovulation, which was not straightforward. At physiological concentrations Ts does not seem to have an effect on the release of LH or ovulation in hens (Croze and Etches, 1980).

Therefore, the present study aimed to study the impact of injection of royal jelly, gibberellic acid and testosterone on some productive performance, egg quality traits and economic efficiency in Matrouh local strain, during summer season, Egypt.

\section{MATERIALS AND METHODS}

The present study was carried out in a Private Farm, near Inshas in Sharkia Governorate, Egypt, during the period from July 2019 to January 2020. 
A total number of 128 laying pullets and 16 cocks of Matrouh local strain at 140 days of age were randomly divided into four treatment groups (32 females and 4 males) in each treatment group as a completely randomized design. Pullets in all treatments were nearly similar in the average initial body weight (936.72 \pm 8.40$)$. Each treatment group was divided into 4 replicates each of 8 hens and one cock in the family's house. Birds were housed (open pens) in 16 floor pens $(2 \mathrm{~m} \times 2 \mathrm{~m})$ furnished with wheat straw and fed ad libitum a basal diet. Fresh water was available all the time during the experimental period 7 months). The basal diet was formulated to meet the NRC (1994) recommendations as shown in Table 1. Birds were submitted to the same managerial condition in a window house with light cycle regimen (16 hours light: 8 hours darkness). Birds were examined against diseases and treated with antibiotics and vaccines to keep them healthy.

The $1^{\text {st }}$ group of pullets was injected with a saline solution $0.9 \%$ and served as control. The $2^{\text {nd }}$ group, was administrated into the beak, with $0.2 \mathrm{ml}$ of distill water, which containing $200 \mu \mathrm{g} \mathrm{RJ} / \mathrm{kg} \mathrm{BW}$ (was purchased from the Khattab Company in Zagazig, Sharkia, Egypt). The $3^{\text {rd }}$ and $4^{\text {th }}$ treatment groups were injected subcutaneously with $0.2 \mathrm{ml}$ of saline solution $0.9 \%$, which containing $200 \mu \mathrm{g} / \mathrm{kg}$ BW of each of GA3 or Ts. Gibberellic acid $\left(\mathrm{GA}_{3}\right)$ was purchased from the Tiba Company in New Salhia, Sharkia, Egypt and Ts, was purchased from the CID Company in Tribal talbieh, Talbieh, Giza, Egypt. All treatment was injected once a week for a month (4 times injections) pre sexual maturity during 20-24 weeks of age.

The average minimum and maximum of ambient temperature (at 7 am and $1 \mathrm{pm})$ during the experimental period ranged between 26.61 and $36.97{ }^{\circ} \mathrm{C}$, relative humidity from 29.00 to $78.75 \%$ and temperature-humidity index (THI) from 19.20 to 28.51 under Inshas, Sharkia Governorate, Egypt as shown in Table 2. THI was estimated according to the formula as follows: $\mathrm{THI}=\mathrm{db}{ }^{\circ} \mathrm{C}-\{(0.31-$ $\left.0.31 \mathrm{RH})\left(\mathrm{db}{ }^{\circ} \mathrm{C}-14.4\right)\right\}$. Where $\mathrm{db}{ }^{\circ} \mathrm{C}=$ bulb temperature in Celsius and $\mathrm{RH}=$ RH\%/100. The values obtained indicate the following: $<22.2=$ Absence of heat stress; 22.2 to $<23.3=$ Moderate heat stress: 23.3 to $<25.6=$ severe heat stress and 25.6 and more $=$ Extreme severe heat stress (Marai et al., 2000).

\section{Laying performance traits:}

Individual body weight (BW) of laying hens before sexual maturity was recorded at 20 weeks and at the end of the experiment (48 weeks). While, the egg number $(\mathrm{EN})$ and egg weight $(\mathrm{EW})$ were recorded daily. Feed consumption (FC) was calculated weekly. The egg production (EP) rate was calculated during the experimental period. Where: 
Table (1): Composition and calculated analysis of the basal diet.

\begin{tabular}{|l|c|}
\hline Ingredients & \% \\
\hline Yellow corn & 61.80 \\
\hline Soybean meal (44\% CP) & 15.10 \\
\hline Wheat bran & 8.28 \\
\hline Corn gluten meal (60\% CP) & 4.75 \\
\hline Dicalcium phosphate & 1.35 \\
\hline Salt & 0.30 \\
\hline Limestone & 8.10 \\
\hline Vit. + Min. premix* & 0.30 \\
\hline DL-Methionine & 0.02 \\
\hline Total & $\mathbf{1 0 0}$ \\
\hline Calculated analysis: & 16.07 \\
\hline Crude protein (CP \%) & 2691 \\
\hline ME; (kcal/kg) & 2.942 \\
\hline Ether extract \% & 3.434 \\
\hline Crude fiber \% & 3.468 \\
\hline Calcium \% & 0.304 \\
\hline Av. Phosphorus \% & 0.653 \\
\hline Lysine \% & 0.314 \\
\hline Methionine \% & 0.608 \\
\hline Methionine + cysteine \% & $1.0 ;$ \\
\hline
\end{tabular}

*Vitamin and mineral premix: added to the $1 \mathrm{~kg}$ of diet including: Vit. A 10000 I.U; Vit. D3

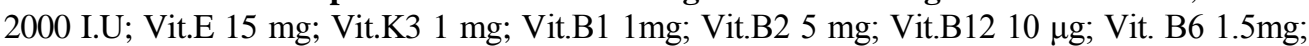
Niacin $30 \mathrm{mg}$; Pantothenic acid 10mg; Folic acid 1mg; Biotin $50 \mu \mathrm{g}$; Choline $300 \mathrm{mg}$; Zinc 50mg; Copper 4mg; Iodine $0.3 \mathrm{mg}$; Iron 30mg; Selenium 0.1mg; Manganese 60mg; Cobalt $0.1 \mathrm{mg}$.

** Calculated analysis according to Feed Composition Tables for Animal and Poultry Feedstuffs used in Egypt (2001).

Table (2): Microclimatic data during the whole experimental period under environmental condition..

\begin{tabular}{|c|c|c|c|c|c|c|}
\hline \multirow{2}{*}{$\begin{array}{c}\text { Summer } \\
\text { months }\end{array}$} & \multicolumn{2}{|c|}{ Average temperature $\left(^{\mathbf{0}} \mathbf{C}\right)$} & \multicolumn{2}{|c|}{ Average RH (\%) } & \multicolumn{2}{|c|}{ Average (THI) } \\
\cline { 2 - 7 } & Min $^{*}$ & Max $^{{ }^{* *}}$ & Min $^{*}$ & Max $^{* *}$ & Min $^{*}$ & Max $^{* *}$ \\
\hline July & $26.61 \pm 0.21$ & $36.97 \pm 0.39$ & $29.00 \pm 1.19$ & $78.75 \pm 1.19$ & 23.92 & 35.48 \\
\hline August & $26.79 \pm 0.19$ & $36.91 \pm 0.32$ & $29.17 \pm 1.32$ & $81.23 \pm 1.46$ & 24.07 & 35.60 \\
\hline September & $24.92 \pm 0.26$ & $34.01 \pm 0.24$ & $36.77 \pm 0.86$ & $80.97 \pm 0.88$ & 22.86 & 32.85 \\
\hline Means & $\mathbf{2 6 . 1 0 \pm 0 . 2 2}$ & $\mathbf{3 5 . 9 6} \pm \mathbf{0 . 3 1}$ & $\mathbf{3 1 . 6 4 \pm 1 . 1 2}$ & $\mathbf{8 0 . 3 1} \pm \mathbf{1 . 1 7}$ & $\mathbf{2 3 . 6 1}$ & $\mathbf{3 4 . 6 4}$ \\
\hline
\end{tabular}


Egg production rate $(\%) / \mathrm{Hen} /$ day $=\frac{\text { Number of eggs produced }}{\text { Number of live hen in each period }} \times 100$ Egg mass was calculated by:

Egg mass, g/day = Egg number/ Hen /day x Avergage egg weight (g).

Feed conversion ratio ( $\mathrm{g}$ feed / $\mathrm{g}$ daily egg mass) (FCR) was also calculated.

The mortality rate $(\%)$ was recorded daily for each treatment from 20 weeks of age to the end of the experiment.

\section{Egg quality measurements:}

Egg quality measurements were determined at 32, 40 and 48 weeks of age, whereas eight eggs from each experimental group were randomly taken to measure egg quality traits and overall means. Egg quality (egg weight, egg shape index $(\%)$, yolk index $(\%)$, albumin index $(\%)$

Percentages of egg components (yolk, albumin and shell weight) relative egg weight were determined. The Haugh score (relationship between egg weight and albumen height) for units and shell thickness in each egg were measured according to Haugh (1937).

\section{Economic efficiency:}

The economic efficiency (EEf) of egg production was calculated from the input/output analysis according to the price of the experimental diets and egg produced during the experimental period. The price of the experimental diets was calculated according to the price of different administrated of doe's injections prevailing in the local market at the time of the experiment. The values of EEf were calculated as the net revenue per unit of total costs.

Relative economical efficiency was calculated assuming that the EEf (\%) of the control $=100$.

\section{Statistical analysis:}

The experiment data were statistically examined by analysis of variance according to Snedecor and Cochran (1982) using ANOVA procedures of SAS (SAS, 2011). The statistical model was used as follows:

$$
\mathbf{Y}_{\mathrm{ij}}=\boldsymbol{\mu}+\mathbf{T}_{\mathbf{i}}+\mathbf{e}_{\mathrm{ij}}
$$

Where, $Y_{i j}=$ An Observation, $\mu=$ Overall mean, $T_{i}=$ Effect of the treatment groups, ( $\mathrm{i}=1,2,3$ and 4$), \mathrm{e}_{\mathrm{ij}}=$ Random error.

The differences between means were tested by using Duncan's multiple range test procedures (Duncan, 1955). 


\section{RESULTS AND DISCUSSION}

\section{Productive performance:}

The effects of royal jelly (RJ), gibberellic acid $\left(\mathrm{GA}_{3}\right)$ and testosterone $(\mathrm{Ts})$ injected on some productive performance of Matrouh hens, during the experimental periods, under Egyptian summer conditions are presented in Table 3.

The significant decrease in body weight is possibly due to reduced feed intake as birds under heat conditions eat less feed in relation to the control ones (Mashaly et al., 2004). The final body weight of Matrouh layers injected with 200 $\mu \mathrm{g}$ Ts, or $\mathrm{GA}_{3}$, / kg BW were significantly $(\mathrm{P} \leq 0.05)$ increased as compared with the control at the end of the experimental period. While the highest values of the LBW and BWG were recorded in the groups injected with $200 \mu \mathrm{g}$ Ts, or $\mathrm{GA}_{3}$, I $\mathrm{Kg}$ BW followed by the same level of RJ (20-48 Wks of age) when compared to the control group (Table 3). The increase in weight due to RJ, GA3 and Ts has effects similar to that of estrogen on hen body weight (Hiba, 2010; Elkomy et al., 2007 and Mohammadi, 2015). From the oldest to the most recent they were showing that the LBW and BWG of the female chicks injected with $200 \mu \mathrm{g}$ RJ, $\mathrm{GA}_{3}$ and Ts increased compared to the control group. These results may be related to the active principles of $\mathrm{RJ}$ and $\mathrm{GA}_{3}$, which was considered to be an excellent feed resource as it contains a wide range of biochemical and nutritionally important substances as: minerals, trace elements, wide range of carbohydrates, organic acids, lipids, sterols, nucleic acids, free amino acids, vitamins and over 100 kinds of enzymes and cofactors (Ismail, 2009 and Ezzat et al., 2020). Also, Hubert et al. (2011) and Mohammadi (2013) reported that testosterone hormone contents increase the resistance of tissues to toxicants and different harmful pathogens, also reported that increase number of goblet cells that acts as a defensive barrier against chemical or mechanical damage and to trapping invading pathogens (Guibert et al., 2012 and Possenti et al., 2016).

Heat stress has been shown to decrease feed intake (from 3947.87 to $3678.23 \mathrm{~g} / \mathrm{bird})$, weight gain (2098.87-1786.77 g/bird), and the FCR (1.88-2.05) in broilers (Jahejo et al., 2016). Results obtained revealed that the effect of RJ, $\mathrm{GA}_{3}$ and Ts treatments on daily feed intake (DFI) and feed conversion per egg (FC) were improved significantly $(\mathrm{P}<0.01)$ at the end of the experimental period. The highest DFI was recorded with the laying hen administrated RJ. It was previously suggested that RJ administration could improve physiological function and immunity, and exert different pharmacological effects (Gabr et al., 2016). The best $\mathrm{FC}$ value (4.94) was recorded with laying hen $\mathrm{GA}_{3}$ injected during the 


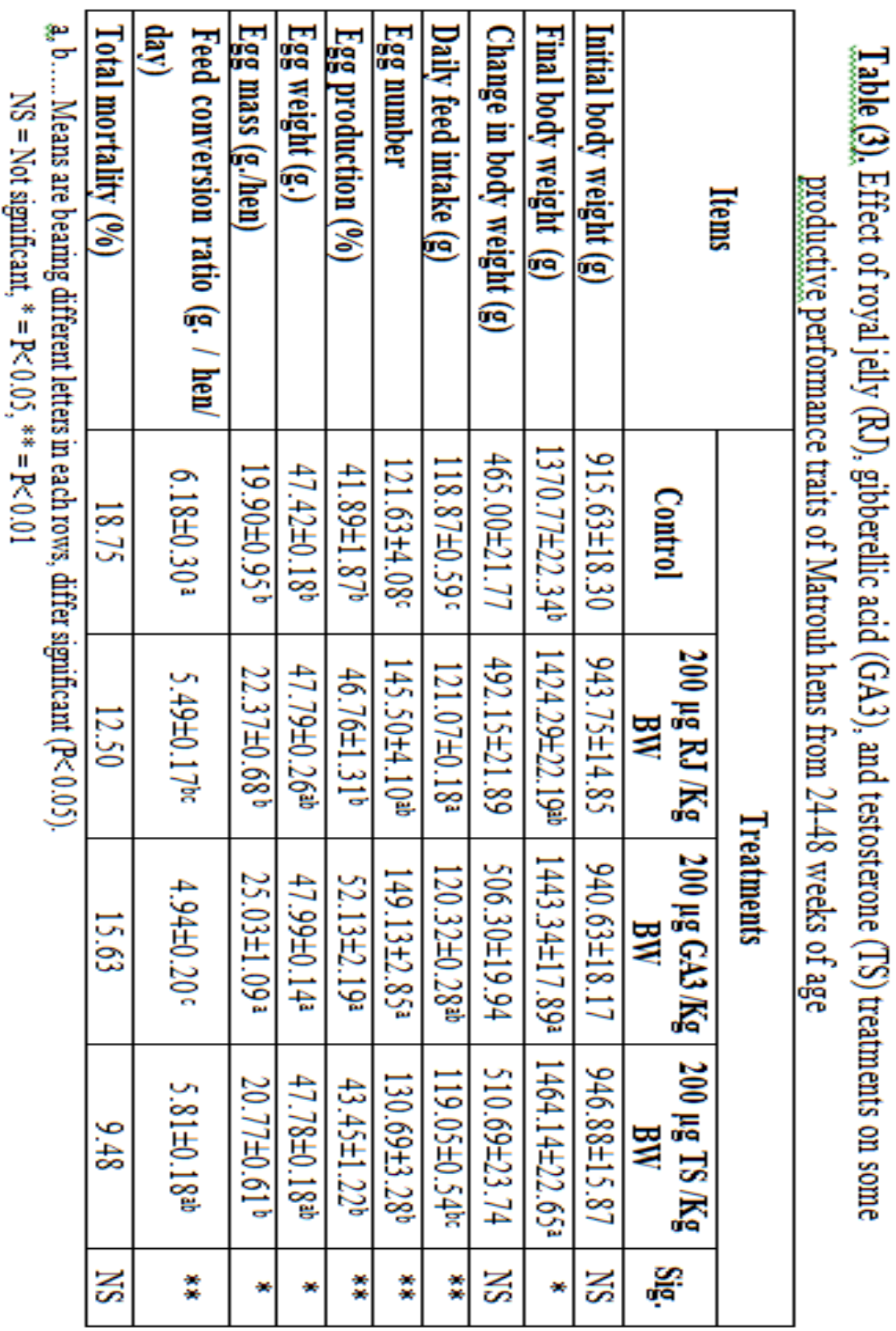


total experimental period (24-48 weeks of age). The present results are in agreement with the finding of El-Afifi and Abou Taleb (2002) reported that $\mathrm{GA}_{3}$ injection improves the significant $\mathrm{FC}$ ratio in laying hen compared to control group. Also, Elkomy et al. (2008) showed that there was a significant differences $\mathrm{FC}$, due to injection laying hens with $200 \mathrm{mg} / \mathrm{Kg} \mathrm{BW}$ of $\mathrm{GA}_{3}$, as compared with the control group.

\section{Egg production traits:}

Results obtained in Table 3 showed that the effect of $\mathrm{GA}_{3}$ injection was significantly $(\mathrm{P}<0.01$ and $\mathrm{P}<0.05)$ increased $\mathrm{EN}, \mathrm{EW}, \mathrm{EM}$ and $\mathrm{EPR}$ at the whole experimental period (24-48 weeks of age) compared to the control group. While, hens treated with $200 \mathrm{mg}$ RJ and $200 \mathrm{mg}$ Ts insignificantly increased EN, EW, EM and EPR when compared to the control group. These results may be due to $\mathrm{GA}_{3}$ mimic estrogen effect. Whereas, estrogen increase sensitive granulose cells for follicle stimulating hormone (FSH) and estrogen synergist with FSH hormone due to increase volume of follicles also estrogen increase motility of oviduct and increase uterus activation (Kirunda et al., 2001) these factors due to increase egg volume and egg weight. This difference may be caused by an increase in FSH and LH hormones (Eriksson et al., 2008) because RJ, GA 3 and Ts increase the activity of the anterior lobe of the pituitary gland responsible for the secretion of these hormones, which increased the ovarian activity and increases the number of mature ovarian follicles, which leads to an increase in egg production during the week and a hen day (HD) production increasing. The best EPR (52.13), EM (25.03) and EW (47.99) were recorded with $\mathrm{GA}_{3}$ injected laying hen at the whole experimental period (24-48 weeks of age). Fariara et al. (2001) showed that there were significant differences in EPR due to injection laying hens with $200 \mathrm{mg}$ $\mathrm{GA}_{3} / \mathrm{Kg} \mathrm{BW}$, as compared with the control group. Mahmoud et al. (1996) Mohammadi et al. (2015) and Miran (2016) demonstrated that, EPR of birds treated with $\mathrm{RJ}, \mathrm{GA}_{3}$ and Ts were higher significantly at the whole experimental period than the control group. Similarly, Muiruri and Harrison, (1991) and Seven et al. (2016) reported that a significant effect $(\mathrm{P} \leq 0.05)$ in $\mathrm{EM}$ at levels $200 \mathrm{mg}$ $\mathrm{GA}_{3} / \mathrm{Kg} \mathrm{BW}$ treatments as well as, in general mean than the control group. $\mathrm{GA}_{3}$ injection has been shown to increase energy, strengthen the immune system, give a positive sense of well-being, and possibly. Causes of all these proposed positive effects, $\mathrm{GA}_{3}$ may be a very important supplement for improving performance of organs body. It has been proposed that $\mathrm{GA}_{3}$ may also, play a significant role in nitric oxide production in the body. Nitric oxide plays an important role in immune system function, sexual health, muscular strength and hypertrophy, as well as other factors; $\mathrm{GA}_{3}$ may therefore be a vital form of the supplementation 
(Mahmoud et al., 1996). The present results are in agreement with the finding of Khalid et al. (2017) observed that there was an improvement in EM due to GA3 injection laying hens as compared to control group. These results may be due to the increasing in egg number. Whereas, $\mathrm{GA}_{3}$ had estrogenic effect and estrogen increase sensitive granulose cells for FSH and estrogen synergist with FSH hormone due to increase volume of follicles also, estrogen increase motility of oviduct and increase uterus activation (Khalil, 1997 and Hamdy et al., 2002). These factors due to increase number of maturation egg and egg volume due to increase egg mass. Overall means that these may be caused to increase of estrogen effect on liver secretion of lipids proteins and this hormone caused increasing in growth of epithelium of the ovary (Mashaly et al., 2004). All the experimental females reached the age of sexual maturity within six months, except for the testosterone group, which was about 15 days later than the rest of the group, which affected the number of eggs produced for injected hens with testosterone when compared to gibberellic acid and Royal jelly groups at the end experimental period.

The lowest mortality rate 9.38 and $12.50 \%$ was recorded with Ts and RJ groups, respectively. While the highest mortality rate 18.75 and $15.63 \%$ was recorded with $\mathrm{GA}_{3}$ and control groups, during the total period (24-48 weeks of age). In birds, variable concentrations testosterone previously have been shown to influence offspring development and growth, metabolic rate, behavior, immune function, the ability to combat oxidative damage, and survival of embryos and nestlings (Tobler and Sandell, 2007; Cucco et al., 2008; Partecke and Schwabl 2008 and Tobler and Sandell, 2009). Testosterone exposure, clutch and sex all had additive effects on mortality. Testosterone enhanced survivorship could potentially increase lifetime reproductive success (Daan and Tinbergen 1997; Stearns, 1992). On the other hand, the present results may be related to the active principles of RJ which, is considered to be an excellent food resource as it contains a wide range of biochemical and nutritionally important substances as: minerals, trace elements, wide range of carbohydrates, organic acids, lipids, sterols, nucleic acids, free amino acids, vitamins and over 100 kinds of enzymes and cofactors which increased the immunity of chickens and reduce the mortality rate (Ezzat et al., 2020).

\section{Egg quality measurements traits:}

Data presented in Table 4 showed that the effect of RJ, GA3 and Ts injection was significantly $(\mathrm{P}<0.01$ and $\mathrm{P}<0.05)$ increased Egg shape index $(\%)$, Egg albumin index and Albumin weight (g) at the whole experimental period (3248 weeks of age) when compared to the control group. While, it was not 


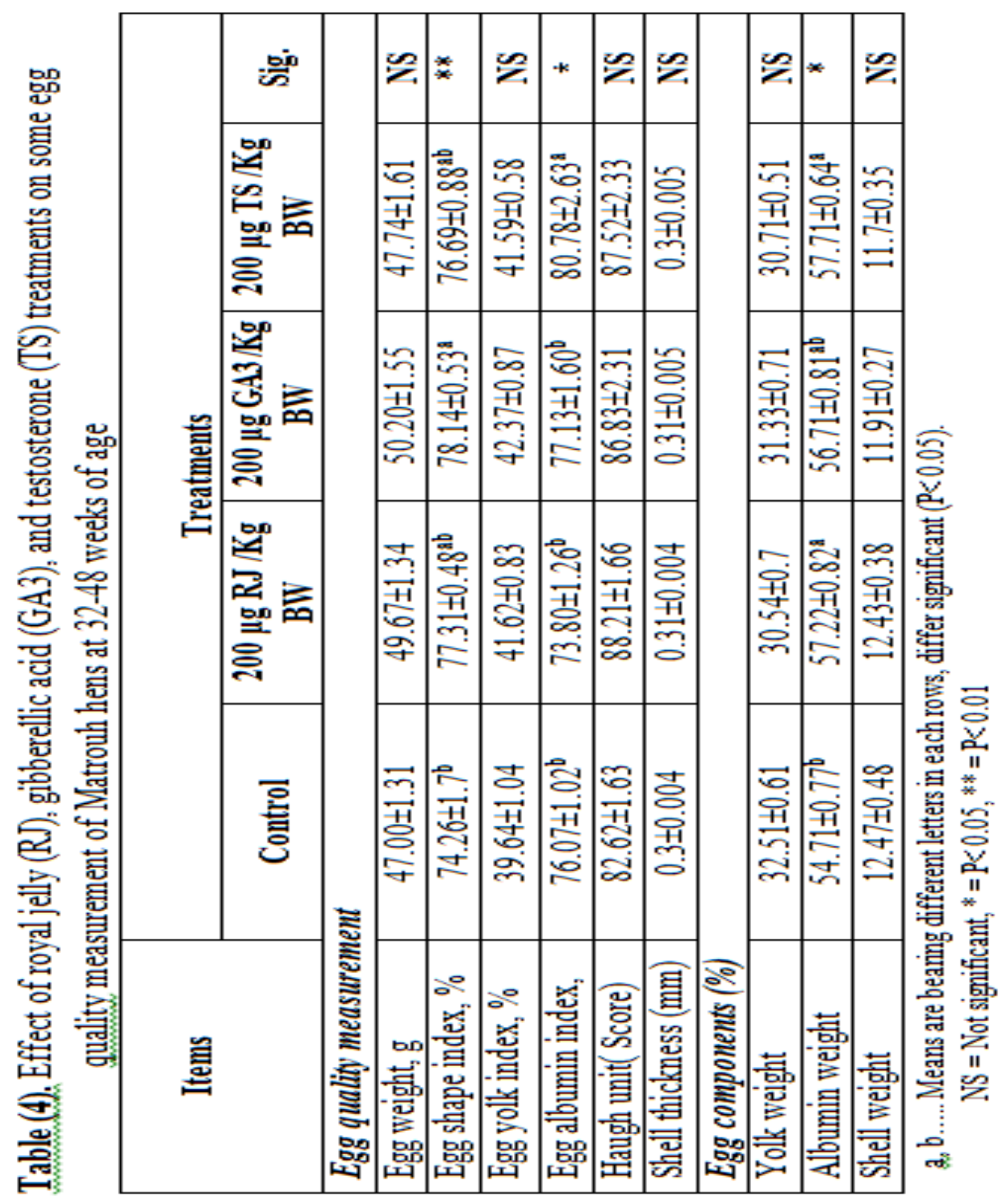


significant $(\mathrm{P}>0.05)$ on Egg weight (g), Egg yolk index (\%), Haugh units (Score), Shell thickness (mm), Yolk weight (g) and Shell weight (g) as compared to the control group.

Heat stress has been shown to a significant decrease in egg shell thickness, egg shell weight, Haugh unit and egg shell strength (Sahin et al., 2018). The best egg weight quality (50.2), egg shape index (78.14), egg yolk index (EYI) (42.37) and egg shell thickness percentage $(0.31 \mathrm{~mm})$ were recorded in laying hen injected with $\mathrm{GA}_{3}$ during period 32-48 weeks of age. $\mathrm{GA}_{3}$ like estrogen effect, estrogen increase sensitive granulose cells for $\mathrm{FSH}$ and estrogen synergist with FSH hormone due to increase volume of follicles also estrogen increase motility of oviduct and increase uterus activation (Khalil, 1997) these factors due to increase egg volume and egg width, consequently the increasing in an egg shape index. El-Afifi and Abo-Taleb (2002) found that estradiol tends to save more blood calcium of laying quail for egg shell deposition. They observed that estradiol can increase intestinal calcium absorption and induce bone turnover, consequently improve egg shell quality and thickness.

Also, the best egg albumin index (80.78), (77.13) was recorded in laying hen treated with $\mathrm{Ts}$ and $\mathrm{GA}_{3}$, respectively. While, the lowest value of egg albumin index (76.07), (73.80) was recorded in the control group and treated with RJ, respectively in laying hen during period 32-48 weeks of age. However, the best Haugh units of egg (88.21), (87.52) were recorded with RJ and Ts group, respectively. While, the lowest value of Haugh units of egg (86.83), (82.62) was recorded with $\mathrm{GA}_{3}$ and control groups, respectively in laying hen during period 32-48 weeks of age. These results are in agreement with those obtained by (Mohammadi et al., 2015) who treated laying hens strain with $500 \mu \mathrm{g} \mathrm{Ts} / \mathrm{Kg}$ $\mathrm{BW}+50,100$ or $150 \mu \mathrm{g} \mathrm{GH} / \mathrm{Kg} \mathrm{BW}$ and showed that the effect of this treatment with different doses on the monthly relative weight of egg albumin were significantly.

The best egg yolk weight (32.51\%), (31.33\%) was recorded with control and $\mathrm{GA}_{3}$ groups, respectively. While the lowest value of yolk ratio (30.54\%), $(30.71 \%)$ was recorded in group treated with RJ and Ts, respectively and the best egg shell weight percentage (12.47) was recorded with control group than the other treatments in laying hen during period 32-48 weeks of age. $\mathrm{GA}_{3}$ has an estrogenic effect due to the increase in egg production and the increase in the number of yolk growth on the ovary, so the percentage of egg yolk was higher than the other groups, but it was not significant, and this effect may be due to the decrease in the weight of the yolk and thus the decrease in the percentage of yolk (Azza El-Sebai et al., 2003). These results may be due to the increase in egg 
production due to treatment by $200 \mathrm{mg} / \mathrm{kg} \mathrm{BW} \mathrm{RJ,} \mathrm{GA} 3$ and Ts concentration (Mohammadi, 2013 and Ezzat et al., 2020). However, results obtained revealed that the effect of $\mathrm{Ts}, \mathrm{RJ}$ and $\mathrm{GA}_{3}$ treatments on egg albumin weight was significant $(\mathrm{P}<0.05)$ increased than the control group in laying hen during period 32-48 weeks of age. These results are in agreement with those obtained by (Mohammadi et al., 2015) who found that laying hens strain treated with $500 \mu \mathrm{g}$ $\mathrm{Ts} / \mathrm{kg} \mathrm{BW}+50,100$ or $150 \mu \mathrm{g} \mathrm{GH} / \mathrm{Kg} \mathrm{BW}$ on the egg albumin weight during the treatment period was significantly. These results are in agreement with those obtained by Elkomy (2003) who add that $200 \mu \mathrm{g} \mathrm{GA} / \mathrm{Kg}$ had the highest egg albumin. $\mathrm{GA}_{3}$ like estrogenic effect, estrogen induced motility of the oviduct may be due to increase albumen production within the oviduct.

\section{Economical Efficiency \% (EE):}

Data presented in Table 5 showed economical efficiency \% (EE) for the treated pullets with $200 \mathrm{mg} / \mathrm{kg} \mathrm{BW} \mathrm{RJ,} \mathrm{GA} 3$, and Ts during the experimental periods as shown in Table 5. Results obtained revealed that the effect of RJ, GA and $\mathrm{Ts}$ treated on EE it was significantly $(\mathrm{P}<0.05)$ during at the end of the experimental period (24-48 weeks of age).

Table 5: Effect of royal jelly, gibberellic acid and testosterone treatments on economical efficiency of egg production of laying Matrouh hens strains, during the experimental period 24-48 weeks of age

\begin{tabular}{|l|c|c|c|c|c|}
\hline \multicolumn{1}{|c|}{ Items } & Control & RJ & GA3 & TS & $\begin{array}{c}\text { Sig. } \\
\text { test }\end{array}$ \\
& & & & & \\
\hline Egg number & $121.63^{\mathrm{c}}$ & $145.50^{\mathrm{ab}}$ & $149.13^{\mathrm{a}}$ & $130.69^{\mathrm{b}}$ & $* *$ \\
Price/egg (LE) & 1.25 & 1.25 & 1.25 & 1.25 & NS \\
Total revenue hen (LE) & $152.03^{\mathrm{c}}$ & $181.88^{\mathrm{ab}}$ & $186.41^{\mathrm{a}}$ & $163.36^{\mathrm{b}}$ & $* *$ \\
Total feed intake/ hen(kg) & 19.97 & 20.34 & 20.21 & 20.00 & \\
Price/Kg feed(LE) & 4.000 & 4.000 & 4.000 & 4.000 & \\
Total feed cost/hen (LE) & 79.88 & 81.36 & 80.85 & 80.00 & \\
Fixed hen (LE) & 3.00 & 6.65 & 3.95 & 6.25 & \\
Total cost hen (LE) & 82.88 & 88.00 & 84.80 & 86.25 & \\
Net revenue/hen(LE) & $69.15^{\mathrm{b}}$ & $\mathbf{9 3 . 8 7 ^ { \mathrm { b } }}$ & $101.61^{\mathrm{a}}$ & $77.11^{\mathrm{b}}$ & $*$ \\
Economic efficiency (EEf) & $\mathbf{8 3 . 4 4 ^ { \mathrm { b } }}$ & $\mathbf{1 0 6 . 6 7 ^ { \mathrm { b } }}$ & $119.82^{\mathrm{a}}$ & $89.41^{\mathrm{b}}$ & $*$ \\
Relative E.Ef. (\%) & 100.00 & 127.85 & 143.60 & 107.16 & \\
\hline
\end{tabular}

a o b..... Means are beaning different letters in each rows, differ significant $(\mathrm{P}<0.05)$.

$\mathrm{NS}=$ Not significant, ${ }^{*}=\mathrm{P}<0.05, * *=\mathrm{P}<0.01$ 
The best economic efficiency $119.82 \%$ and $106.67 \%$ was recorded with $\mathrm{GA}_{3}$ and RJ groups, respectively. While, the lowest value of economical efficiency $89.41 \%$ and $83.44 \%$ were recorded in the Ts and control groups, respectively in pullets during at the end of the experimental period (24-48 weeks of age). The same results were obtained by Ezzat et al. (2020), result showed that the clearer that Matrouh layers injected with $200 \mu \mathrm{g}$ of $\mathrm{GA}_{3} / \mathrm{kg} \mathrm{BW}$ were recorded the highest net revenue and the best economical efficiency followed by those $100 \mu \mathrm{g}$ of $\mathrm{GA}_{3} / \mathrm{kg} \mathrm{BW}$ as compared with the control groups, while 50 or $100 \mu \mathrm{g}$ of $\mathrm{RJ} / \mathrm{kg} \mathrm{BW}$ had the lowest net revenue and economical efficiency (\%).

Conclusively, pullets treated with $200 \mu \mathrm{g} \mathrm{GA}_{3}$ or RJ $/ \mathrm{kg}$ BW during presexual maturity of age (20-24 weeks) were recommended for improving most of the productive performance, as well as egg quality and had the highest net return and economic efficiency of Matrouh local strain under summer season conditions in Egypt.

\section{REFERENCES}

Abdel-Azim, B.A. 2017. Toxicological study of gibberellic acid on liver, kidney and brain and its apostasy in adult albino rats. Res. J. Pharm. Biol. Chem. Sci., 8:443-450.

Abdel-Fattah, S.A.; Soliman, N.K.; Afifi, Sh.F. 2007. Effect of dietary cholecalciferol levels and gibberellic acid on productive and reproductive traits, serum profile and bone minerlization of laying quail. Egypt. Poultry Sci., 27: 785-803.

Abd-Elhamid, A.M.; Dorra, T.M.; Ali, M.A. and Abuo-Egla, E.H. 1994. Effect of gibberellic acid on broiler chickens performance and some metabolic parameters. Arch. Anim. Nutr., 46: 269-276.

Askar, A.A. and IsmaeIl, E.I. 2012. Effect of gibberellic acid on some physiological; reproductive and hatchability parameters of laying hens during winter and summer seasons. Egypt. J. Anim. Prod., 49 (1):77-86.

Azza El-Sebai, A. M. and Elnagar, S.A. 2003. Physiological effects of gibberellic acid (GA3) on female Japanese quail production and reproduction. Egypt. Poultry. Sci., 23: 977- 999.

Croze, F. and Etches, R.J. 1980. The physiological significance of and rogen induced ovulation in the hen. The Journal of Endocrinology 84:163-171.

Cucco, M.; Guasco, B.; Malacarne, G.; Ottonelli, R. and Tanvez, A. 2008. Yolk testosterone levels and dietary carotenoids influence growth and immunity of grey partridge chicks. Gen. Comp. Endocrinol., 156:418-425. 
Daan, S. and Tinbergen, J.M. 1997. Adaptation of life histories. In: Krebs JR, Davies NB (eds) Behavioral ecology: an evolutionary approach, $4^{\text {th }} \mathrm{edn}$. Wiley, New York,:311-333.

Duncan, D.B., 1955. Multiple range and multiple F tests. Biometrics, 11:1-42.

El-Afifi, S.h.F. and Abou Taleb, A.M. 2002. Calcium absorption and deposition in old egg-laying Japanese quail as affected by dietary supplementation with estradiol and cholicalciferol. Egypt. Poult. Sci., 22 (III): 855-868.

El-Hanoun, A. M.; Elkomy, A. E.; Fares, W. A. and Shahien, E. H. 2014. Impact of royal jelly to improve reproductive performance of male rabbits under hot summer conditions. World Rabbit Sci., 22 (3): 241-248.

Elkomy, A. 2003. Physiological studies on Gibberellic acid (GA3) and reproduction function of adult fowl. Ph. D. Thesis. Faculty of Agric., Alexandria University, Alexandria. Egypt.

Elkomy, A.E.; Samar E.A. and Azza El-Sebai 2007. Steroidogenic effects of gibberellic acid (GA3) on chicks. Egypt. Poult. Sci., 27(4): 1239-1255.

Elkomy, A.E.; El-Shaarrawi, G.; El-Ansary, E. and Elnagar, A.A. 2008. Evaluation of estrogenic response to subcutaneously injection of gibberellic acid (GA3) in aged female fowl. Egypt. Poult. Sci.,Vol. (28) (IV):12651286.

Elnagar, S. A.; Elghalid, O. A. and Abd-Elhady, A. M. 2010. Royal jelly: Can it reduce physiological strain of growing rabbits under Egyptian summer conditions? Animal., 4 (9): 1547-1552.

Eriksson, J.; Larson, G.; Gunnarsson U.; Bed'hom, B. and Tixier-Boichard, M. 2008. Identification of the yellow skin gene reveals a hybrid origin of the domestic chicken. PLos Genetics. 4 (2) : 1-8.

Ezzat, W.; Rizk, A.M.; Hanan S. Mohamed and Fathey, I.A. 2020. Effect of gibberellic acid and royal jelly injection on some productive, reproductive and physiological traits in Matrouh chickens strain during summer season. J. Product. \& Dev.., 25 (2): 169-194.

Fariara, D.E. Jun queira, O.M; Souza, P.A. and Titto, E.A.I. 2001. Performance, body temperature and egg quality of laying hens fed vitamins D and C under three environmental temperatures," Braz. J. of Poult. Sci. 3: 49-56.

Feed Composition Tables For Animal and Poultry Feedstuffs Used In Egypt, 2001. Technical bulletin No.1, central lab for Feed and food; Ministry of Agric., Egypt. 
Fraps, R.M. 1955. Egg production and fertility in poultry. In 'Progress in the physiology of farm animals'. Vol. 2. (Ed. J Hammond). 671-740. (Butterworths: London).

Gabr, S.h. A.; Younan, G. E.; Hamad, M. E.; Rehab, Ismail S. A. and Mervat, Sh. M. Z. 2016. Effect of some natural antioxidants on growth performance, blood parameters and carcass traits of growing rabbits under Egyptian summer condition. J. Anim. and Poult. Prod., Mansoura University. 7 (12): 457- 466.

Gawienowski, A.M. and Chatterijee, D. 1980. Effect of prostaglandin inhibitor on the uterotrophic response of estradiol and gibberellic acid. Life Sci., 27: 1393-1396.

Goerlich, V.C.; Dijkstra, C. and Groothuis, T.G.G. 2010. Effects of in vivo testosterone manipulation on ovarian morphology, follicular development, and follicle yolk testosterone in the homing pigeon. The J. of Exp. Zoology, 313A, 328-338.

Guibert, F; Richard-Yris, M.A., Lumineau, S.; Kotrschal, K.; Möstl, E. and Houdelier C. 2012. Yolk testosterone levels and offspring phenotype correlate with parental age in a precocial bird. journal physbeh. doi: 10.1016. 18;105 (2) : 242-50.

Guo, H.; Kouzuma, Y. and Yonekura, M. 2007. Structures and properties of antioxidative peptides derived from royal jelly protein. Food Chemistry, 113 (1): 238-245.

GUO, H; Ekusa A.I; Iwai K; Yonekura M; Takahata, Y. and Morimatsu, F. (2008). Royal jelly peptides inhibit lipid peroxidation in vitro and in vivo. Journal. Nutrition. Science. Vitaminol. 54, 191-195.

Hamdy, A.M.M; Esa, N.M. and Bakir, A.A. 2002. Prediction of egg production by some body measurements and plasma steroids hormones. Egypt. Poult. Sci., 22: (1) 205-218.

Hang, G.; Ekusa, A.; Iwai, K.; Yonekura, M.; Takahata, Y. and Morimatsu, F. 2008. Royal jelly peptide inhibit lipid proxidation in vitro and in vivo. J. of Nutr. Sci. and Vitaminology, 54 (3): 191-195.

Haugh, R. R. (1937). The Haugh unit for measuring egg quality. United States Egg Poultry Magazine, 43, 552-553.

Hiba, O. A. E. (2010). Effect of Royal jelly on Humoral Antibody Response, Blood Chemistry and Performance of Broiler \&Layer Chickens. Faculty of Sci. University of Khartoum. 
Hidaka, S.; Okamoto, Y.; Uchiyama, S.; Nakatsuma, A.; Hashimoto, K.; Ohnishi, S. T. and Yamaguchi, M. 2006. Royal jelly prevents osteoporosis in rats: Beneficial effects in ovariectomy model and in bone tissue culture model. Advance Access Publication, 3: 339-348.

Hubert, S.; Donna, H.; Rosemary, S. and Alex, S. (2011). Embryonic exposure to maternal testosterone influences age-specific mortality patterns in a captive passerine bird. DOI 10.1007/s11357-011-9222-8.

Ikeda, Y.; Washizuka, M.; Furuichi, H.; Fukuda, Y.; and Kuwabara, Y. 1996. Stress and royal jelly. Honeybee Sci., 17 (3): 103-110.

Ismail, E.A, 2009. Physiological and reproductive studies on laying hens. Ph. D. Thesis, Faculty of Agric., Zagazig Univ., Zagazig, Egypt.

Khalid, C.h.; Al-salhieand, K.; Sabah, K. and Al-hummod, M. 2017. Effect of injected with gibberellic acid (GA3) on some productive and physiological traits of aged Japanese quail. Al-Furat J. of Agric. Sci. / Second National Scientific Conference of Vet. Medicine: 10-23.

Khalil, M. H., 1997. Endocrinology Hand Bock,: 258- 273.

Kirunda, D.F.K.; Scheideler, S. E. and Mckee, S.R. 2001. The efficacy of vitamin $\mathrm{E}$ (DL- $\alpha$-tocophyryl acetat) supplementation in hen diets to alleviate egg quality seterioration associated with high temperature exposure. Poult. Sci., 80:1378-1383.

Maghsoudlou, A.; Mahoonak, A. S.; Mohebodini, H. and Toldra, F. 2019. Royal jelly: Chemistry, storage and bioactivities. J. of Apicultural Sci., 63 (1): $17-40$.

Mahmoud, K.Z.; Beck, M.M.; Scheideler, S.E.; Forman, M.F.; Anderson, K.P. and Kachman, S.D. 1996. Acute high environmental temperature and calcium-estrogen relationships in the hen. Poult. Sci., 75 (12): 1555-1562.

Marai, I.F.M.; Bahgat, L.B.; Shalaby, T.H. and Abdel-Hafez, M.A. 2000. Fattening performance, some behavioral traits and physiological reactions of male lambs fed concentrates mixture alone with or without natural clay under hot summer of Egypt. Ann. Arid Zone (India) 39: 449-460.

Mashaly, M.M.; Hendricks, G.L.; Kalama, M.A.; Gehad, A.E.; Abbas, A.O. and Patterson, P.H. 2004. Effect of heat stress on production parameters and immune responses of commercial laying hens. Poult. Sci. 83: 889-894.

Miran, S. N. 2016. Effects of propolis, royal jelly, honey and bee pollen on growth performance and immune system of Japanese quails. Veterinary Research Forum, 7: 13-20. 
Mohammadi, H. 2013. Effects of testosterone and growth hormone injection on production performance and egg quality at the late phase of reproduction. Department of Agriculture, Payame Noor University, Tehran, IRAN. PO BOX 19395-3697.

Mohammadi, H.; Ansari-Pirsaraei. Z.; Mousavi. S. N.; Bouyeh. M.; Gholibeikifard, A.; Nouri, P.; Hatefi. .A. and Rahmani. M. 2015. Egg quality and production performance of laying hens injected with growth performance and testosterone in the late phase of production. Article in Animal Production Science. January 2015. Https: // www. research gate. net / publication / 276254482.

Muiruri, H.K. and Harrison, P.C., 1991. Effect of roost temperature on performance of chickens in hot ambient environments. J. Poult. Sci., 70: 2253-2258.

Mutibvu, T.; Chimonyo, M. and Halimani, T.E. 2017. Physiological responses of slow-growing chickens under diurnally cycling temperature in a hot environment. Braz. J. Poult. Sci., 19: 567-576.

Nagai, T.; Nagashima, T.; Myoda, T. and Inoue, R. 2004. Preparation and functional properties of extracts from bee bread. Food/nahrung, 48(3): 226-229.

NRC, (1994). Nutrient Requirements of Poultry.9th rev. ed. National Academy Press, Washington, DC.

Partecke, J. and Schwabl, H. 2008. Organizational effects of maternal testosterone on reproductive behavior of adult house sparrows. Dev. Neurobiol, 68:1538-1548.

Pawar, S.S.; Sajjanar, B.; Lonkar, V.D.; Kurade, N.P.; Kadam, A.S.; Nirmal, A.V.; Brahmane, M.P. and Bal, S.K. 2016. Assessing and mitigating the impact of heat stress on poultry. Adv. Anim. Vet. Sci., 4(6):332-341

Pehlivan, T.; Mansour, A.; Spaczynski, R.Z. and Duleba, A.J. 2001. Effects of transforming growth factors $\alpha$ and $\beta$ on proliferation and apoptosis of rat theca-interstitial cells. J. of Endocrinology, 170: 639-645.

Possenti, D.C.; Romano, A.; Caprioli, M.; Rubolini, D.; Caterina, S.N.S. and Parolini, M. 2016. Yolk testosterone affects growth and promotes individual-level consistency in behavioral lateralization of yellow-legged gull chicks. J. homepage Hormones and Behavior 80: 58-67.

Sabatini, A. G.; Marcazzan, G. L.; Caboni, M. F.; Bogdanov, S. and AlmeidaMuradian, L. B. D. 2009. Quality and standardisation of royal jelly. Journal of Api Products and Api Medical Sci., 1 (1): 16-21. 
Sahin, N.; Hayirli, A.; Orhan, C.; Tuzcu, M.; Komorowski, J.R. and Sahin, K., 2018. Effects of the supplemental chromium form on performance and metabolic profile in laying hens exposed to heat stress. Poult. Sci. 97 (4), 1298-1305.

SAS (2011). Base SAS 9.3 Procedure Guide: Statistical Procedure. Cary, NC, USA.

Seven, P. T.; Sur, A.A.; Özçelik, M.; Gülcihan, Ş.Ü. and Seven, İ. 2016. Effects of propolis and royal jelly dietary supplementation on performance, egg characteristics, lipid peroxidation, antioxidant enzyme activity and mineral levels in Japanese quail. European Poult. Sci., 80: 1-16.

Silva, A.L.L.; Rodrigues, C.; Costa, J.L.; Machado, M.P.; Penha, R.O.; Biasi, L.A.; Vandenberghe, L.P.S. and Soccol, C.R. 2013. Gibberellic acid fermented extract obtained by solid-state fermentation using citric pulp by Fusarium moniliforme: Influence on Lavandula angustifolia Mill. cultivated in vitro. Pakistan J. of Botany. 45 (6): 2057-2064.

Snedecor, G.W. and Cochran, W.G. 1982. Statistical Methods. $7^{\text {th }}$ Edition, Iowa State University Press, Towa, 511.

Stearns, S.C. 1992. The evolution of life histories. Oxford University Press, Oxford.

Tobler, M. and Sandell, M.I. 2007. Yolk testosterone modulates persistence of neophobic responses in adult zebra finches, Taeniopygia guttata. Horm Behav. 52:640-645.

Tobler, M. and Sandell, M.I. 2009. Sex-specific effects of prenatal testosterone on nestling plasma antioxidant capacity in the zebra finch. Journal Exp. Biol., 212:89-94.

Vandana, G. D.; \& Sejian, V.; Lees, A. M.; P. Pragna, P.; Silpa, M. V. and Shane K. Maloney. 2021. Heat stress and poultry production: impact and amelioration. Int. J. Biometeorol., 65:163-179.

Yahav, S. and McMurty, J. P. 2001. The rmotolerance acquisition in broiler chickens by temperature condition early in life. The effect of timing and ambient temperature. Poult. Sci., 80: 1662-1666. 


\section{تأثثير المعاملة بالرويال جيلي وحمض الجبريليك والتستشتيرون علي الصفات

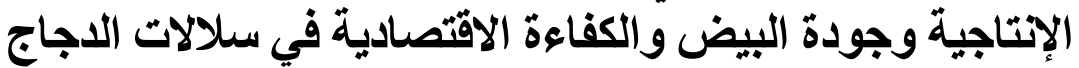

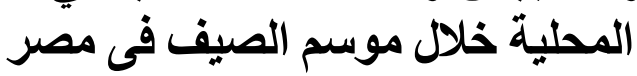

احمد عبدالوهاب جمعة**ـ على عبد العظيم رشوان* ـ مصطفى ابر اهيم توفيق* ـ حسن

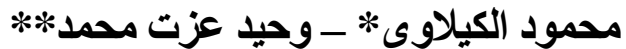
* قسم الاتتاج الحيو انى و الداجنى ـكلية التكنولوجيا و التنميةـ جامعة الزقازيقـ الزقازيقـ*** قسم بحوث تربية الدواجن - معهد بحوث الانتاج الحيوانىـ الاقى - جيزة - مصر.

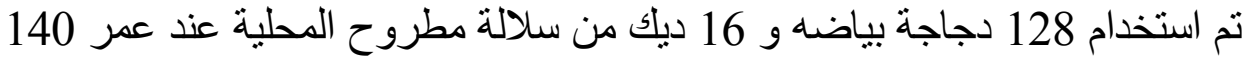

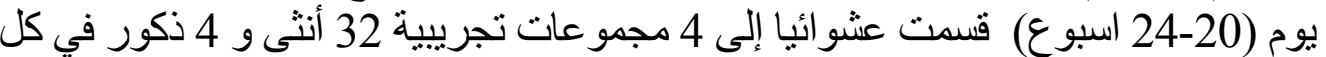

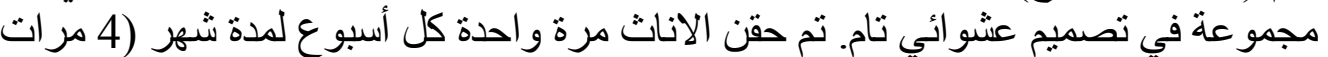

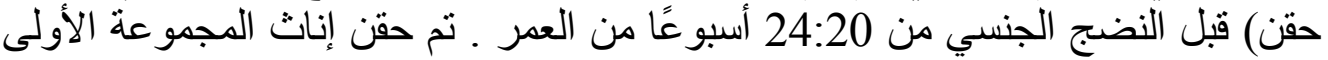

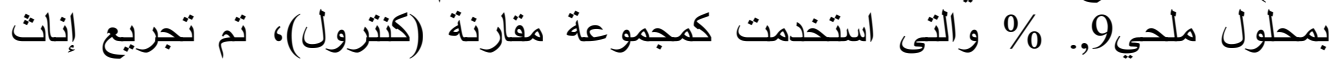

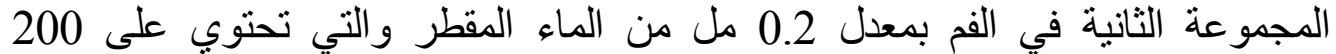

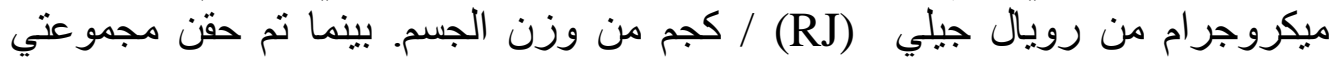

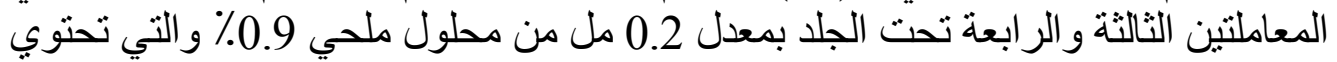
على 200 ميكروجر ام من كلا من حمض الجبريليك (GA3) و التستوستيرون (Ts) على التى

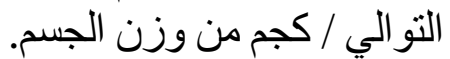
وأظهرت النتائج تحسن معنويـا (عند مستوي احتمـال 0,05) في وزن الجسم الجنم النهائي

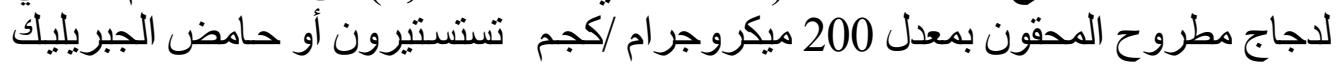

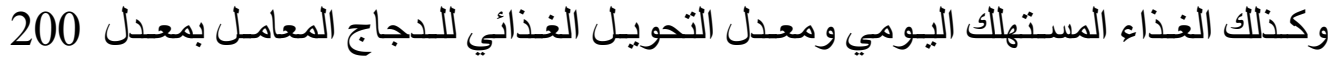

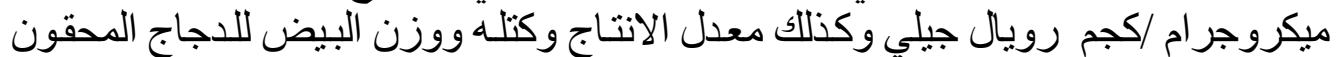

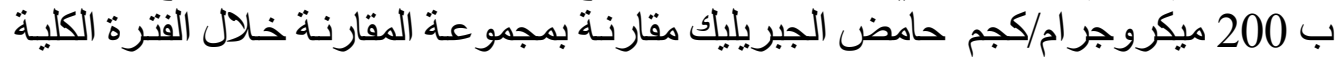

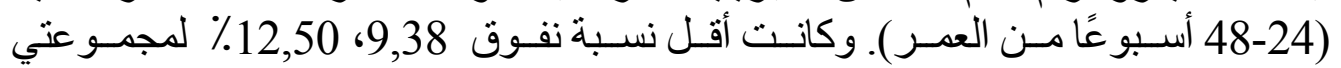

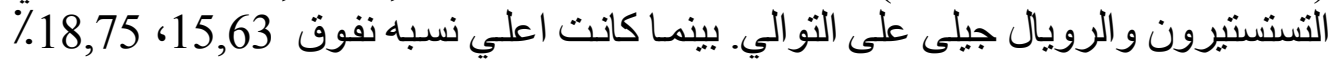

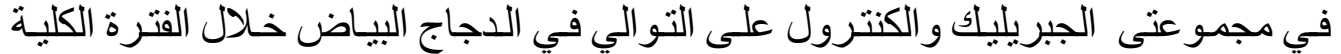

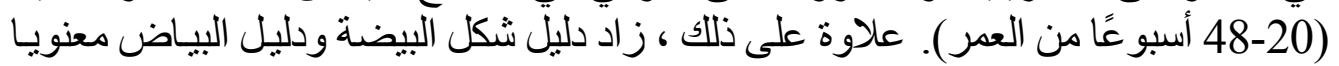

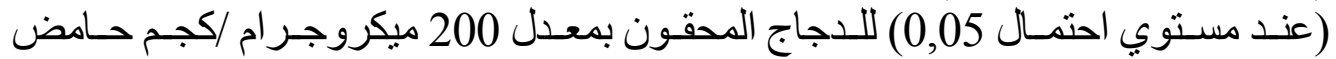

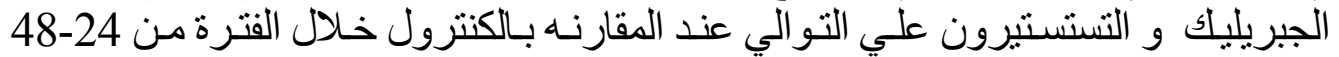




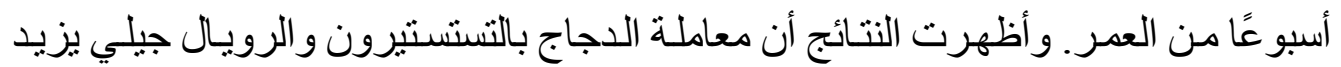

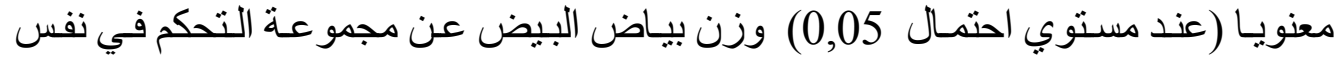

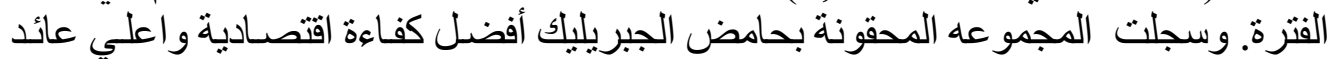

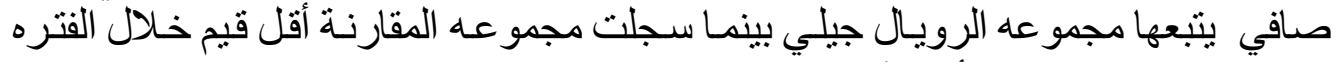
التجريبيه الكليه (20-48 أسبو بعًا من آلعمر ).

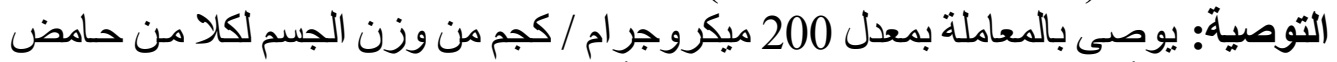

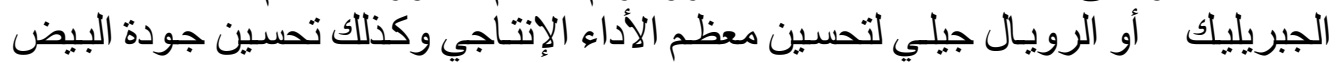

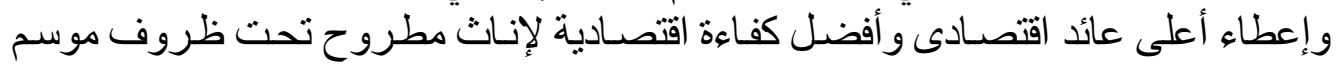
الصيف في مصر. ألمعر 